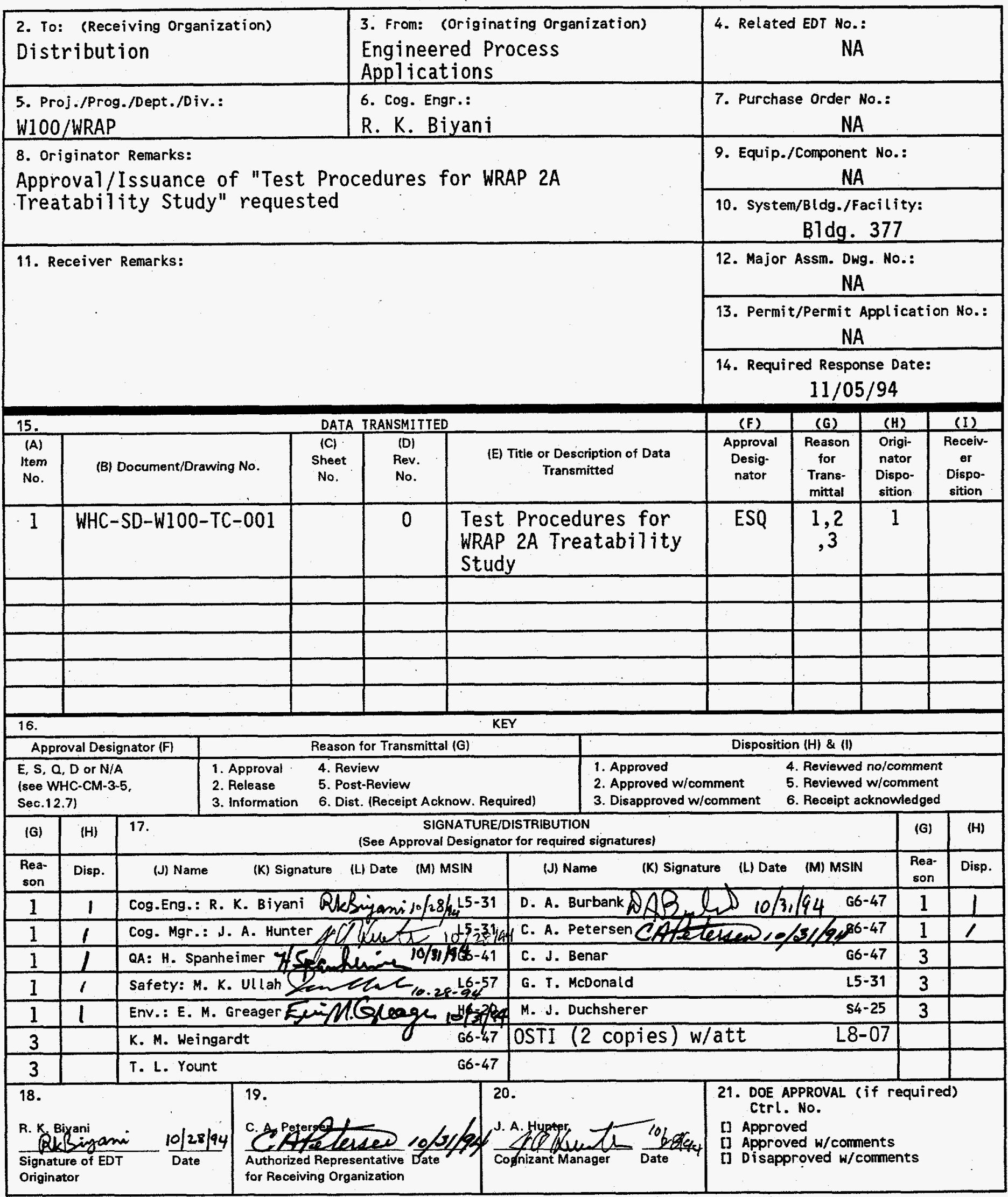

BD-7400-172-2 (04/94) GEF097 


\section{RELEASE AUTHORIZATION}

Document Number: WHC-SD-W100-TC-001, Revision 0

Document Title: Test Procedures for WRAP 2A Treatability Study

Release Date: $\quad$ October 31, 1994

This document was reviewed following the procedures described in WHC-CM-3-4 and is:

APPROVED FOR PUBLIC RELEASE

WHC Information Release Administration Specialist:

M. Bostar

$10 / 31 / 94$

\section{M.N. Boston}

TRADEMARK OISCLAIMER. Reference herein to any specific conmercial product, process, or service by trade name, trademark, manufacturer, or otherwise, does not necessarily constitute or imply its endorsement, recommendation, or favoring by the United states Government or any agency thereof or its contractors or subcontractors.

This report has been reproduced from the best available copy. Available in paper copy and microfiche. Printed in the United States of America. Available to the U.S. Department of Energy and its contractors from:

U.S. Department of Energy

Office of Scientific and Technical Information (OSTI)

P.0. Box 62

Oak Ridge, TN 37831

Telephone: (615) 576-8401

Available to the public from:

U.S. Department of Commerce National Technical Information Service (NTIS) 5285 Port Royal Road

Springtield, VA 22161

Telephone: (703) 487-4650 
2. Title

3. Number

WHC-SD-W100-TC-001

6. Author

5. Key Words

Treatability, Cementitious, 183-H Basin, Sludge, Test, Procedures, WRAP 2A

Name: R. K. Biyani
4. Rev No.

0

RKBigani

Organization/Charge code

$8 A 700 / A 5533$

7. Abstract

This document describes operating procedures to prepare and test cementitious specimens designed to immobilize $183-\mathrm{H}$ basin waste.

8. RELEASE STAMP

OFFICIAL RELEASE

EYWho

DATE NOV 021994

35

Station 21 


\section{DISCLAIMER}

Portions of this document may be illegible in electronic image products. Images are produced from the best available original document. 


\title{
TEST PROCEDURES FOR WRAP 2A TREATABILITY STUDY
}

\author{
R. K. Biyani \\ Westinghouse Hanford Company
}

October 1994

\section{DISCLAIMER}

\begin{abstract}
This report was prepared as an account of work sponsored by an agency of the United States Government. Neither the United States Government nor any agency thereof, nor any of their employees, makes any warranty, express or implied, or assumes any legal liability or responsibility for the accuracy, completeness, or usefulness of any information, apparatus, product, or process disclosed, or represents that its use would not infringe privately owned rights. Reference herein to any specific commercial product, process, or service by trade name, trademark, manufacturer, or otherwise does not necessarily constitute or imply its endorsement, recommendation, or favoring by the United States Government or any agency thereof. The views and opinions of authors expressed herein do not necessarily state or reflect those of the United States Government or any agency thereof.
\end{abstract}


WHC-SD-W100-TC-001 REV. 0

THIS PAGE INTENTIONALLY LEFT BLANK 


\section{WHC-SD-W100-TC-001 REV. 0 \\ TEST PROCEDURES FOR WRAP 2A \\ TREATABILITY STUDY}

TABLE OF CONTENTS

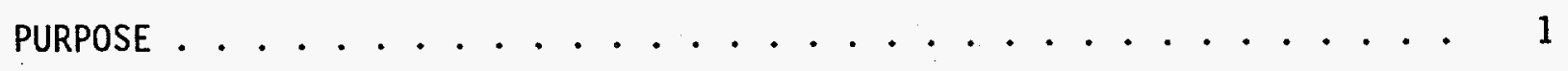

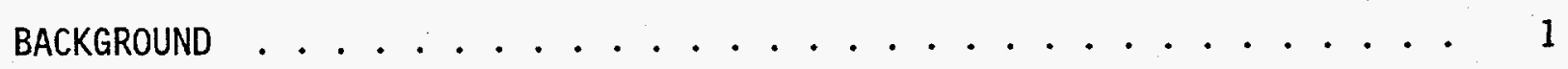

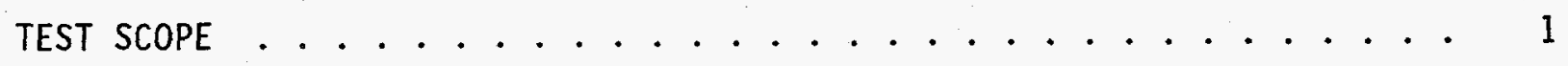

SAFETY . . . . . . . . . . . . . . . . . 1

Preparation of Cementitious Mixtures and Specimens ........ 3

Viscosity ........................ 7

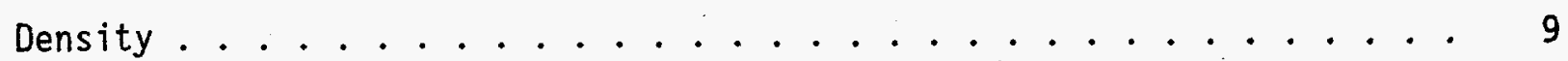

Percent Drainable Liquid . . . . . . . . . . . . . 9

Time of Setting ........................ 11

Compressive strength . . . . . . . . . . . . . 13

Modified ANSI 16.1 Leach Test . . . . . . . . . . . . 17

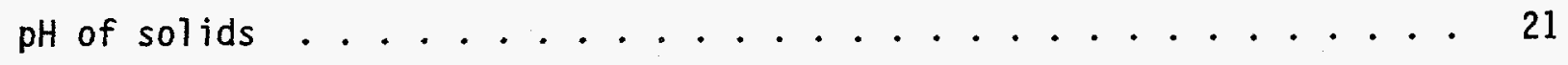

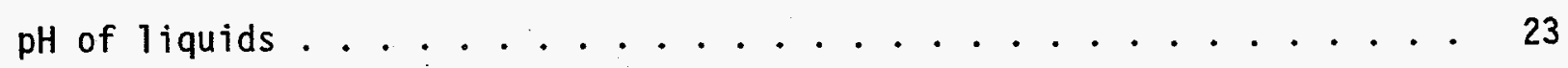

90-Day Water Immersion ................. 25

Toxicity Characteristic Leaching Procedure (TCLP) . . . . . . . 27

References ................... 33

\section{LIST OF TABLES}

Containers Used for the Preparation of Cementitious Specimens . . . . 4

Total Elapsed Time at Leachant Changeout ............ 19

TCLP Sample Maximum Holding Times ............... 31 
WHC-SD-W100-TC-001 REV. 0

\title{
LIST OF ACRONYMS
}

\author{
ANS American Nuclear Society \\ ANSI American National Standards Institute \\ ASTM American Society for Testing \& Materials \\ DIW Deionized water \\ JHA Job Hazards Analysis \\ MW Mixed Waste \\ PR Penetration Resistance \\ TCLP Toxicity Characteristic Leaching Procedure \\ USEPA U. S. Environmental Protection Agency \\ WRAP Waste Receiving and Processing
}


WHC-SD-W100-TC-001 REV. 0

\section{TEST PROCEDURES FOR WRAP 2A TREATABILITY STUDY}

\section{PURPOSE}

This document gives stepwise, procedural instructions to prepare and test cementitious specimens using 183-H basin sludge samples. The treatability test results will support the design of the Waste Receiving and Processing ModuTe 2A (WRAP 2A) treatment system.

\section{BACKGROUND}

The WRAP $2 A$ facility will encapsulate retrieved, stored, and newly generated contact-handled mixed waste (MW) into 200 to $1900 \mathrm{~L}$ (55 to $500 \mathrm{gal}$ ).

cementitious forms at the Department of Energy's Hanford Site near Richland, Washington.

\section{TEST SCOPE}

Test methods described here are derived from recent surrogate waste testing procedures' which incorporate.ASTM and ANSI guidelines. Specimen preparation will involve mixing the MW sludge sample with a mixture of Type I-II portland cement, fly ash, and water. The formulation, specified in the Program Plan ${ }^{2}$, consists of equal weights of waste, cement, fly ash, and water. Tests to be performed are listed below

Photograph (color, texture, cracks, irregularities)

Bulk Density, uncured/cured

Viscosity

Curing time/Hardness

As cured/Compressive Strength

Leachability Index

Water Immersion/Compressive Strength

Free Liquids Evaluation

Toxicity Characterization

Corrosivity ( Leachate $\mathrm{pH}$ )

Significant deviations from the working procedures described here will be documented in a test report after completion of the work.

\section{SAFETY}

Although this document does not contain a separate section on safety, the safety of operating personnel has been kept in mind while writing every step of the procedures. Safety has been further addressed by conducting and documenting a Job Hazard Analys is (JHA) for potentially hazardous activities (e.g. compression tests). 
WHC-SD-W100-TC-001 REV. 0

THIS PAGE INTENTIONALLY LEFT BLANK 


\author{
WHC-SD-W100-TC-001 REV. 0 \\ Preparation of Cementitious Mixtures and Specimens
}

\title{
SCOPE
}

This procedure describes the mechanical mixing of dry cementitious solids blends with waste sludges to form a slurry which will solidify and immobilize the hazardous components.

\section{APPLICATION:}

This procedure is applicable to both non-radioactive and low level activity cementitious mixtures.

\section{MATERIALS AND APPARATUS:}

1. Hobart ${ }^{\circledR}$ bench top variable speed mixer, a four liter stainless steel mixing bowl and a high efficiency paddle/impeller

2. Graduated cylinder, $1000 \mathrm{~mL}$

3. Precision balance with a capacity of 3000 grams and readability of 0.1 gram

4. $50 \mathrm{~mm}$ dia $\times 100 \mathrm{~mm}$ tall (2" $\left.\times 4^{\prime \prime}\right)$ cement curing molds with press-on caps

5. $88 \mathrm{~mm} \times 75 \mathrm{~mm}\left(3 \frac{1}{2} " \times 3^{\prime \prime}\right)$ poly-jar with screw cap lid

6. Liquid Scintillation Vials, $25 \mathrm{~mm}$ dia $\times 60 \mathrm{~mm}$ high ( ${ }^{\prime \prime} \times 2 \% "$ )

7. Plastic or glass tamping rod, $6 \mathrm{~mm}$ dia $\times 200 \mathrm{~mm}\left(\frac{1}{4} " \times 8 "\right)$

8. Vibrating table

9. Flat stainless steel spatula

10. Spatula made of Tef7on ${ }^{\circledR}$

11. Plastic ladle to fill molds

12. Type "F" fly ash

13. Type I-II portland cement

14. $1 \mathrm{~kg}$ sludge sample from Basin 183-H.

15. WHC controlled Laboratory notebook to record al1 test results. 


\section{PROCEDURE:}

1. Spray the inside surface of all the molds with a mold release silicone or Teflon ${ }^{\circledR}$ spray.

2. Weigh and label the eleven sample curing molds with the sample numbers as shown in Table 1. Using an indelible ink pen write the tare weight (inclusive of the cap weight) on the bottom of the specimen molds for the compressive strength samples.

Table 1. Containers Used for the Preparation of Cementitious Specimens for the WRAP-2A Treatability Test.

\begin{tabular}{||c||c|c|c|c||}
\hline $\begin{array}{c}\text { SAMPLE } \\
\text { NO. }\end{array}$ & QUANTITY & $\begin{array}{c}\text { VOLUME } \\
(\mathrm{m}])\end{array}$ & $\begin{array}{c}\text { DIMENSIONS } \\
\text { Diam. X length }\end{array}$ & PURPOSE \\
\hline $1,2,3$ & 3 & 206 & $50 \mathrm{~mm} \times 100 \mathrm{~mm}$ & As cured Comp. Strength. \\
\hline $4,5,6$ & 3 & 206 & $50 \mathrm{~mm} \times 100 \mathrm{~mm}$ & $\begin{array}{c}90 \text {-Day Immersion } \\
\text { Comp. Strength }\end{array}$ \\
\hline 7,8 & 2 & 30 & $25 \mathrm{~mm} \times 60 \mathrm{~mm}$ & Modified ANSI 16.1 Leach \\
\hline $9,10,11$ & 3 & 500 & $88 \mathrm{~mm} \times 75 \mathrm{~mm}$ & Penetrometer \\
\hline
\end{tabular}

3. Maintain the laboratory temperature for mixing between $20^{\circ} \mathrm{C}$ and $25^{\circ} \mathrm{C}$.

4. Bring the temperature of the dry solids blend, waste solutions and the mixer to within the above temperature range at the time of mixing.

5. (a) Measure and record the $\mathrm{pH}$ of the waste.

(b) Record the tare weight of the mixing bow1. Transfer the entire contents of the waste sample container to the mixing bowl. Weigh the mixing bowl again to obtain a weight of the total sludge sample to be solidified. Record this weight (say $x$ gms) in the laboratory notebook. For this test the same amount ( $x$ gms) of water, fly ash, and cement will be used in preparing the cementitious slurry.

6. Assemble the mixing apparatus in a laboratory hood by placing the stainless steel mixing bowl onto its stand and securing the mixing impeller inside the mixer chuck.

7. Next, weigh the dry solids (fly ash and cement) into separate plastic weighing boats and set them aside. Record this weight in the laboratory notebook.

8. Measure and add deionized water to the bow1 as required in the formulation. 
9. Turn the mixer on Tow speed, and mix until the sludge is well mixed (approx. 3 minutes). Adjust the mixer speed taking care to avoid splattering. Use a stop watch to measure the mixer speed in rpm and the mixing time. Record these values in the laboratory notebook.

10. Slowly add the fly ash, then the cement, to the bowl containing the surrogate/water mixture. Stop the mixer temporarily and scrape the sides of the mixing bowl with the Teflon ${ }^{\circledR}$ spatula to ensure a homogeneous blend of the components. Do not attempt to dislodge any settled or unmixed material from the sides of the bowl without switching off the mixer. Record any changes made to the mixing speed. Continue mixing for 2-3 minutes. Record the mixing time.

11. Stop the mixer. Use a suitable amount (about $500 \mathrm{ml}$ ) of slurry to perform the Fann ${ }^{\circledR}$ viscosity measurements. This should take no more than 5 minutes. Upon completion of the viscosity tests, transfer the slurry into the appropriately labeled molds as listed in Table 1 . Fill the compressive strength molds first, followed by the ANSI mold, and the penetrometer molds.

12. Pour or scoop the cementitous slurry into each mold. If the slurry is thick, fill half of each mold, place on vibrating table for 15-20 seconds, then fill the rest of the mold. Overfill each mold slightly. Tamp the slurry with a glass or plastic rod if necessary, and vibrate the specimen again for 15-20 seconds to eliminate/minimize air pockets. Level the top of each specimen using the edge of the stainless steel spatula. Wipe off the outside of the mold.

13. Place caps onto each of the "compressive strength" molds, being careful not to disturb the "trowelled" surface. Weigh the specimen to the nearest $0.1 \mathrm{~g}$, and record the weight in a laboratory notebook.

14. Place the molds into a $473 \mathrm{ml}(16 \mathrm{fl} .0 \mathrm{z}) \mathrm{glass}$ jar and secure the 7 id. Apply a couple wraps of plastic tape to ensure that the jar is a ir tight. Label the container with the date of mixing for the batch.

15. Follow step 12 for filling the remaining ANSI and penetrometer test specimens, place the caps, seal with tape and set aside.

16. Clean/wash the mixing beaker and impeller and blot dry with clean paper towels. Collect waste liquids in a polyethylene carboy and waste solids in a metal drum. Label both containers appropriately.

17. Manage all liquid and solid radioactive wastes per the facility's LLW certification plan. 
WHC-SD-W100-TC-001 REV. 0

THIS PAGE INTENTIONALLY LEFT BLANK 


\section{WHC-SD-W100-TC-001 REV. 0 \\ Determination of Viscosity \\ of Freshly Prepared Cementitious Mixtures \\ Using a FANN@ Viscometer}

\section{SCOPE:}

This method describes the determination of viscosity of a cementitious mixture using a FANN ${ }^{\circledR}$ viscometer.

\section{APPARATUS and MATERIALS:}

1. FANN@ viscometer and accessories set up with a R1-B1-F1 configuration for the Rotor-Bob-Spring Force.

2. Freshly prepared cementitious mixture.

\section{PROCEDURE:}

NOTE: This procedure is to be performed in a laboratory hood. When working with radioactive slurries and rotating equipment take extra precaution to prevent the spread of contamination by splashing.

1. Clean the rotor and bob of the viscometer. Examine for dents, abrasion, or other damage. If damaged, replace the damaged part with one in good mechanical condition.

2. Clean the sample cup of the viscometer. The sample cup has a line at the proper level to hold $350 \mathrm{~mL}$.

3. Wipe dry the sample cup, bob, and rotor of the viscometer.

4. Attach the bob to the bob shaft and the rotor to its socket. Twist the bob around the shaft bearing gently to tighten.

5. Fill the sample cup with the freshly prepared cementitious mixture to the proper level $(350 \mathrm{ml})$.

6. Place the sample cup on the viscometer platform/stage.

7. Lock the cup to the platform/stage.

8. Raise the cup up to the scribed line on the rotor sleeve by raising the platform using the locking knob.

9. Connect the viscometer to the proper power source (115 V).

10. Turn motor on, select the desired speed and read the shear stress value 
WHC-SD-W100-TC-001 REV. 0

$\phi\left(1^{\circ}\right.$ Fann $\left.\simeq 1 \mathrm{lb} / 100 \mathrm{ft}^{2}\right)$ from the dial located on the viscometer head.

11. Repeat step 10 for four different speeds $(600,300,200,100)$ of the viscometer (in that order). Complete step 11 quickly. Record the value of the shear stress for each speed (shear rate) into table in the laboratory notebook. Record the time taken to complete viscosity measurements.

12. Refer to Reference 1 for guidance on calculation of apparent viscosity. 
WHC-SD-W100-TC-001 REV. 0

\section{Determination of Density, Percent Drainable Liquid and Drainable Liquid pH for 28-Day Cured Cementitious samples}

\section{SCOPE:}

This method is used to determine the 28-day cured sample bulk density of cementitious mixtures, the volume percent drainable liquid and the $\mathrm{pH}$ of drainable 7 iquid at the surface of 28-day cured samples.

\section{APPLICATION:}

This procedure is applied for the determination of drainable liquid/water in 28-day cured cementitious samples prepared from Basin 183-H sludges.

\section{THEORY}

Typical wastes may contain a high concentration of salts which, depending on the formulation, may sometimes not be fully incorporated into the cement matrix. The excess solutions, being less dense than the solidified cement, may therefore appear as a free liquid on the surface.

\section{MATERIALS}

1. Plastic specimen mold, $50 \mathrm{~mm}$ dia $X 100 \mathrm{~mm}$ tall, $\approx 206 \mathrm{~mL}$.

2. Graduated cylinders $10 \mathrm{~mL}$ with $0.1 \mathrm{~mL}$ graduations.

3. Plastic disposable pipets $10 \mathrm{~mL}$, graduated, Serological or Mohr type.

4. Freshly prepared cementitious mixture.

\section{PROCEDURE:}

1. Introduce the freshly prepared cementitious mixture into a $50 \mathrm{~mm}$ diameter $X 100 \mathrm{~mm}$ high $(\approx 206 \mathrm{~mL})$ plastic specimen mold that has been previously weighed.

2. Cap the plastic mold tightly to prevent the evaporation of bleed water.

3. Allow the sample to cure for 28 days inside of a sealed secondary container at ambient temperature.

4. After 28 days, withdraw any drainable liquid at the surface of the sample into the graduated pipet and record the volume of liquid to the nearest $0.1 \mathrm{ml}$ (depending on the type of pipet used, it may be necessary to suck the total volume of the liquid up into the graduated portion of the pipet in order to obtain an accurate measurement). 


\section{WHC-SD-W100-TC-001 REV. 0}

5. Dispense the liquid into a $15-30 \mathrm{ml}$ plastic beaker and screen/measure the $\mathrm{pH}$ using $\mathrm{pH}$ indicating paper by transferring a small drop of 1 iquid onto $\mathrm{pH}=0-14$ range paper. DO NOT DIP THE PAPER INTO THE LIQUID.

6. Remeasure the $\mathrm{pH}$ using $\mathrm{pH}$ indicating paper with a more narrow $\mathrm{pH}$ range. Choose paper that is appropriate for the acidity range of the sample. Record the $\mathrm{pH}$.

7. Remove the 28-day cured specimen from the cylinder mold and measure its length and diameter to the nearest 0.1 millimeter using a dial caliper. Record the dimensions in a laboratory notebook.

8. Place the cement specimen onto an electronic balance and measure its weight in grams to the nearest $0.1 \mathrm{~g}$. Record the weight.

\section{CALCULATIONS}

1. Calculate the cured volume of the cylindrical cementitious specimen in $\mathrm{cm}^{3}$ using equation 1 .

$$
\begin{aligned}
& \text { Volume } \\
& \text { VMT }
\end{aligned}=\pi\left(\frac{D}{2}\right)^{2} H \quad(\text { eqn. } 1)
$$

Where $D=$ Measured diameter of cured cylindrical specimen, in $\mathrm{cm}$. $\mathrm{H}=\mathrm{He}$ ight of the cured cylindrical specimen, in $\mathrm{cm}$.

2. Calculate the volume percent drainable liquid using equation 2.

$$
\text { \&FreeLiquid }=\frac{\text { Volume }_{H_{2} \mathrm{O}}}{\left(\text { Volume }_{\mathrm{H}_{2} \mathrm{O}}+\text { Volume }_{\mathrm{CMT}}\right)} \times(100) \quad \text { (eqn.2) }
$$

Where Volume $_{\mathrm{H} 20}=$ The volume of liquid, in milliliters.

Volume $_{\mathrm{CMT}}=$ The volume of the cured cylindrical specimen (eqn. 1), in $\mathrm{cm}^{3}$.

3. Calculate the dry density of the cement specimen in $\mathrm{g} / \mathrm{cm}^{3}$ using equation 3 .

$$
\rho_{D R Y}=\frac{\operatorname{Mass}_{C M T}}{\text { Volume }_{C M T}}
$$

Where: Mass $_{\mathrm{CMT}}=$ The mass of the cured cylindrical specimen, in grams. Volume $_{\text {CMT }}=$ The measured volume of the cured cylindrical specimen (eqn.1), in $\mathrm{cm}^{3}$. 


\section{WHC-SD-W100-TC-001 REV, 0 \\ Time of Setting of Cement-Based mixtures \\ by Penetration Resistance}

\section{$\underline{\text { SCOPE }}$}

This method ${ }^{3}$ describes the determination of the time of setting of cement-based mixtures by means of penetration resistance.

\section{APPLICATION}

This procedure is applicable to Basin 183-H sludge mixed with cementitious materials.

\section{LIMITATION}

1. The temperature of the air in the vicinity of the mixing laboratory, the dry solids blend and molds shall be maintained between $20^{\circ} \mathrm{C}$ and $27.5^{\circ} \mathrm{C}$.

2. If the specimens are not cured in closed containers, the relative humidity of the laboratory should not be less than $50 \%$. If used, the curing box/cabinet shall be so constructed as to provide storage facilities for test specimens at a relative humidity of not less than $90 \%$.

\section{APPARATUS AND MATERIALS}

1. Forney penetrometer equipped with a secondary "memory" needle that moves with the indicating needle to the indicated pressure, then remains at that pressure until reset.

2. Specimen molds ( $p$ lastic cylinders with a diameter of $88 \mathrm{~mm}$ and minimum height of at least $75 \mathrm{~mm}$ ), with screw-on 1 ids.

3. Vibrating table

4. Freshly prepared cementitious mixture

5. Dial calipers

\section{PROCEDURE:}

1. Fill the specimen molds with the freshly prepared cementitious mixture up to about $10 \mathrm{~mm}$ below the top edge of the molds and to a depth of at least $50 \mathrm{~mm}$.

2. Compact the mixture by placing the molds on a vibrating table and vibrating them for at least one minute.

3. Cover the molds with caps that fit the molds.

4. Store and maintain the specimens at room temperature (approx. $23^{\circ} \mathrm{C}$ ) and 
WHC-SD-W100-TC-001 REV. 0

allow them to set for 24 hours.

5. After 24 hours, remove any bleed water from the sample surface using a plastic pipet, and save it in a suitable, closeable container to prevent evaporation (this will be returned to the top of the specimen after the penetrometer test is complete).

6. Select a proctor needle of the appropriate size depending upon the state of hardening of the sample (starting with $645 \mathrm{~mm}^{2}\left(1^{1{ }^{2}}\right)$ bearing area). Insert the needle into the penetration resistance apparatus and bring the bearing surface of the needle into contact with the sample surface. The needle should be positioned at least $25 \mathrm{~mm}$ from the edge of the container, and the clear distance between needle impressions shall be at least two diameters of the needle being used, but not less than $10 \mathrm{~mm}$. Zero the pressure gauge's "memory" needle.

7. Gradually and uniformly apply a vertical force downward on the apparatus lever arm until the needle penetrates the sample to a depth of $25 \mathrm{~mm}$ as indicated by the scribe mark. The time to reach the $25 \mathrm{~mm}$ scribe mark should be ten seconds.

8. Record the pound force $\left(1 b_{f}\right)$ required (as indicated by the "memory" needle on the pressure gauge, proctor needle size, and the time of application, measured as elapsed time after initial contact of the dry-solids cementitiousing materials with the simulated waste solution.

9. If the sample is reusable, return any bleed water, to the sample surface, place the screw cap onto the mold, and return the specimen to its storage location.

10. Repeat steps 5 through 9 at intervals suitable to the formulation e.g. elapsed times 48,72 and 96 hours, or until, a hardness of $3.45 \mathrm{MPa}$ $\left(5007 b_{f} / i^{2}\right.$ is reached for each specimen.

11. Record the time, date, gauge readings and needle size for each sample penetration resistance test.

\section{CALCULATIONS}

1. Calculate the Penetration Resistance (PR) in pounds force per square inch (psi) as the force required to cause a $25 \mathrm{~mm}$ depth of penetration of the needle divided by the area of the bearing face of the needle.

2. Convert the penetration resistance (PR) units of $1 b_{f} /$ in $^{2}$ to newtons per square meter $\left(\mathrm{N} / \mathrm{m}^{2}\right)$ using equation 4 , and record this value.

$P R\left(N / m^{2}\right)=P R\left(I b_{f} / i n C h^{2}\right) \times 6.895 \times 10^{3}$

(eqn. 4) 


\section{WHC-SD-W100-TC-001 REV. 0 \\ Compressive Strength of Cement-based samples}

\section{$\underline{\text { SCOPE }}$}

This method describes the determination of the compressive strength. of cement-based samples ${ }^{4}$.

\section{APPLICATION}

This procedure is applicable to Basin 183-H sludge mixed with cementitious materials. This procedure is suitable for use with a Soiltest@ Model. CT-755 compression testing machine.

\section{APPARATUS AND MATERIALS}

1. $50 \mathrm{~mm} \times 100 \mathrm{~mm}$ (diameter $X$ height) right circular cylindrical cement specimens, cured the same number of days ( \pm 1 day) from the mixing date (minimum of 28 days).

2. Soiltest Model CT-755, $114,000 \mathrm{~kg}(250,000 \mathrm{1b})$ capacity concrete testing machine, spacers for $50 \mathrm{~mm} X 100 \mathrm{~mm}$ specimens, and conforming to ASTM C 39 specifications. Machine must be calibrated annually to ASTM, Practices E 4 and $E 74$ requirement.

4. Plastic bags, $4 \mathrm{~L}$ capacity.

5. Masking tape.

6. Humboldt ${ }^{\circledR}$ heating pot for melting sulfur capping compound.

\section{PROCEDURE}

1. Remove any drainable liquid. Record the volume (to the nearest $0.1 \mathrm{ml}$ ) measure the $\mathrm{pH}$ with 7 itmus paper to the nearest $0.5 \mathrm{pH}$ unit.

2. Remove the cement specimen from the mold by cutting the plastic mold using a plastic cutting "hot knife". Cut the bottom off, then cut vertically down the side.

3. Weigh the specimen to the nearest $0.1 \mathrm{~g}$.

4. Carefully inspect the specimen for irregularities (air pockets, cracks, graduation in color/texture). Record the findings for each specimen.

5. Photograph (or camcord) each sample.

6. Measure the diameter and length twice at, midpoints, to the nearest $0.2 \mathrm{~mm}$, rotating the specimen approximately $90^{\circ}$ so that an average determination can be made. Use a caliper directly readable to 0.001 " (standard) or 
WHC-SD-W100-TC-001 REV. 0

$0.02 \mathrm{~mm}$ (metric). Record the dimensions in $\mathrm{mm}$. These readings are to be used for density calculations also.

7. Sulfur cap the samples to be tested.

Safety Note: This step requires handling a molten sulfur based compound which may result in burns if it comes in contact with the skin. Exercise utmost care when transferring this material.

In the laboratory hood melt about $1 \mathrm{~kg}$ of Cylcap ${ }^{\circledR}$ sulfur capping compound in the Humboldt ${ }^{\circledR}$ pot (at $115-120^{\circ} \mathrm{C}$ setting). Let the surface of the cement specimen air dry if it is not already dry. Put on heat resistant gloves and, using a metal dipping ladle, carefully pour about 20-30 ml of molten sulfur into the cavity of the cylinder capper. Mount the cement specimen to be capped in the vertical cylinder capper. After 10-15 seconds the sulfur will solidify and the specimen may be removed by tapping the base of the capper lightly with a hammer. Repeat capping procedure on the opposite end of this specimen as well as for the other specimens.

8. Place the lower bearing block and the $50 \mathrm{~mm} \times 100 \mathrm{~mm}$ specimen spacer directly under the upper bearing block.

9. Wipe the bearing block faces clean.

10. Carefully place the specimen in the testing machine below the center of the upper bearing block.

11. Place the sample inside a plastic bag and seal the bag with tape to collect fragments of specimen that fall off during compression. These fragments will be saved for TCLP analysis.

12. Carefully align the vertical axis of the specimen with the center of the upper block. Use the concentric rings on the lower bearing block (platten) as a guide.

13. Turn on the compression machine power and ensure that the digital readout is set to $\mathrm{kgs}$.

14. Secure the latch on the protective shield to protect personnel from fragmented cement pieces.

15 Apply the load continuously and without shock, at a maximum rate of $28 \mathrm{~kg}$ to $71 \mathrm{~kg} / \mathrm{sec}(63 \mathrm{lb}-157 \mathrm{lb} / \mathrm{sec})$ for a $50 \mathrm{~mm}$ diameter cylindrical sample). DO NOT ADJUST THE RATE OF MOVEMENT AT ANY TIME AFTER THE FIRST HALF OF THE ANTICIPATED LOADING HAS BEEN REACHED.

16. Apply the load until the specimen fails, and record the maximum load $\left(\mathrm{L}_{\text {Max }}\right)$ carried by the specimen during the test. Record the type of load and the appearance of the cement and note how the specimen fractured, e.g. conically. 


\section{WHC-SD-W100-TC-001 REV. 0}

17. Remove the plastic bag containing pieces of specimen and clean the work area with a brush.

18. Separate the Cylcap ${ }^{\circledR}$ material from the sample. Collect $250 \mathrm{~g}$ of the fractured specimen and set aside for the TCLP test if applicable.

19. Repeat steps 9-18 for each specimen.

\section{CALCULATIONS}

1. Calculate the cross sectional surface area of the specimen in square meters (eqn. 5).

$$
\text { Area }=\frac{\pi D^{2}}{4} \times \frac{m^{2}}{10^{4} \mathrm{~cm}^{2}} \quad(\text { eqn. 5) }
$$

Where:
$\pi=\quad 3.1416$
$D=\quad$ The diameter of the specimen, in $\mathrm{cm}$
Area $=\quad$ The cross sectional area of the sample in square meters.

2. Calculate the compressive strength of the specimen by dividing the maximum load by the cross-sectional area. Express the result (eqn. 6) in $\mathrm{kilopascals}\left(1 \mathrm{kPa}=\mathrm{kN} / \mathrm{m}^{2}\right)$.

$$
C S=\frac{\left(L_{\text {Max }}\right)\left(g_{c}\right)}{A r e a} \times \frac{k N}{1000 N} \quad(\text { eqn. } 6)
$$

Where:

$$
\begin{array}{rlrl}
L_{\text {Max }} & = & \text { The maximum load applied to failure, in } \mathrm{kg} . \\
\mathrm{g}_{c}= & \text { The gravitational constant }\left(9.81 \mathrm{~m} / \mathrm{s}^{2}\right) \\
\text { Area } & = & \text { The cross sectional area of the specimen, in } \mathrm{m}^{2} \\
\mathrm{CS}= & \text { The compressive strength, in } \mathrm{kPa} .
\end{array}
$$


WHC-SD-W100-TC-001 REV. 0

THIS PAGE INTENTIONALLY LEFT BLANK 
WHC-SD-W100-TC-001 REV. 0

Modified ANSI 16.1 Leach Test

\section{$1.0 \quad$ SCOPE}

This procedure describes how to conduct a modified ANSI/ANS-16.1 shortterm leach testing procedure ${ }^{5}$. This procedure is intended to provide controlled and easily attainable conditions for the comparative evaluation of waste retention in waste forms. Subjects covered by this procedure include sample preparation, calculation of leachate volume, preparation of leach vessels, sampling procedure, and description of related calculations.

This procedure does not deal with the reduction of data from the chemical analysis of leachates because this is covered in the source ANSI 16.1 procedure. This procedure describes only the specific practices used for these tests to accomplish the physical test requirements of ANSI 16.1. Minor schedule changes have been incorporated into this procedure to accommodate the work week and to reduce analytical costs. This includes the requirement to start the initial leach on a Monday or Tuesday morning. These changes do not affect the necessary boundary conditions of the standard procedure.

Modifications to the procedure include

- A modified schedule of leachate changeout (see Table 2)

- Analyses of bottle rinses are not conducted

- Filter media are discarded without being analyzed.

\subsection{DEFINITIONS}

Leach Test: Experiment in which a sample of known surface area is submerged in a fluid to determine the rate at which various chemical species in the sample are dissolved.

\subsection{EOUIPMENT}

3.1 Calipers (Accuracy: $\pm 0.03 \mathrm{~mm}$ )

3.2 Balance (Accuracy: $\pm 0.1 \mathrm{~g}$ )

$3.3500 \mathrm{ml}$ polypropylene wide mouth bottles; two bottles are required for each sample. Two bottles allow the sample to be placed in a cleaned bottle with fresh leachant while leachate from the other bottle is being sampled. Rinse the bottles three times with deionized water (DIW) before use.

3.4 Nylon Monofilament - Tie monofilament into a loop then slip loop around the sample and tighten the knot securely so that the sample 
WHC-SD-W100-TC-001 REV. 0

may be suspended from a hole in the cap of the leaching bottle.

3.5 Scintillation vials - Rinse each vial, at least once, with a small amount of filtered leachate before filling it with an aliquot of the filtered leachate for analysis (see 3.6).

3.6 Syringe and $0.45 \mu \mathrm{m}$ syringe filters. - Label one syringe for each sample leached. This syringe will be rinsed and reused throughout the test for filtering leachates from this sample only. In preparation for sampling, each syringe should be rinsed well with the leachate to be filtered as follows: Pour leachate into the syringe and replace the plunger. Shake the syringe to make sure that the plunger tip is rinsed. Squeeze out the remaining rinse leachate. Remove the plunger and place a filter on end of the syringe. Pour leachate into the syringe, replace the plunger and rinse the filter and sample vials (see 3.5) by filtering a minimum of $5 \mathrm{~mL}$ of leachate into each of the sample vials. Syringes should be rinsed with DIW and allowed to dry between intervals.

3.7 Calibrate the $\mathrm{pH}$ meter using $\mathrm{pH} 7$ and 10 buffered standards. Record calibration slope and temperature (Follow Instruction Manual).

3.8 Cured cementitous waste surrogate specimen, approximately $2.5 \mathrm{~cm} \mathrm{X}$ $3.0 \mathrm{~cm}$ right circular cylinders (diam. $X$ length).

\subsection{PROCEDURE}

\subsection{PRECAUTIONS}

4.1.1 Leachate solution pH can approach 12.5. Appropriate eye protection must be worn when processing samples.

4.1.2 Surgeon's gloves must be worn to prevent skin contamination by exposure to samples.

4.1.3 After sampling collect all excess leachate in a polyethylene carboy. Do not dispose of leachate down the drain.

\subsection{INSTRUCTIONS}

4.2.1 Record all data in a laboratory notebook. Ensure that all balances are in calibration. Record measurements and the results of calculations as they are called out in the procedure below.

4.2.2 Lightly wipe the samples with a soft-bristled brush to remove any loose material that may be left on the samples while removing the samples from the molds. 
4.2.3 Weigh the sample and record the weight to nearest $0.1 \mathrm{~g}$.

4.2.4 Measure diameters and lengths twice, rotating samples approximately $90^{\circ}$ so that average determinations can be made.

4.2.5 Calculate the amount of leachant by determining the surface area of the sample and multiplying by 10. Calculation of surface area is found in section 4.3

4.2.6 Fill a leach bottle with the calculated volume of DIW.

4.2.7 Suspend the sample near the center of the DIW-filled leaching bottle using monofilament threaded through a hole in the lid. Record the test start time.

4.2.8 The leachant will be changed out as described in the "Elapsed Time" table below. When a changeout period is near the replacement bottle should be rinsed and filled with fresh DIW leachant. Changeout is accomplished simply by removing the lid, with the suspended sample, from the first bottle and transferring it to the bottle containing the fresh leachant.

Table 2. Total Elapsed Time at Leachant Changeout

\begin{tabular}{|c|c|c|}
\hline $\begin{array}{l}\text { Leach } \\
\text { Interval }\end{array}$ & $\begin{array}{l}\text { Modified } \\
\text { Schedule }\end{array}$ & $\begin{array}{l}\text { ANSI 1 } \\
\text { Schedu }\end{array}$ \\
\hline $\begin{array}{lr}\text { int } & 0 \\
\text { int } & 1 \\
\text { int } & 2 \\
\text { int } & 3 \\
\text { int } & 4 \\
\text { int } & 5 \\
\text { int } & 6 \\
\text { int } & 7 \\
\text { int } & 8 \\
\text { int } & 9 \\
\text { int } & 10\end{array}$ & $\begin{array}{rr}0 & \mathrm{~h} \\
7 & \mathrm{~h} \\
1 & \mathrm{~d} \\
2 & \mathrm{~d} \\
4 & \mathrm{~d} \\
7 & \mathrm{~d} \\
14 & \mathrm{~d} \\
28 & \mathrm{~d} \\
56 & \mathrm{~d} \\
91 & \mathrm{~d} \\
\end{array}$ & $\begin{array}{ll}30 & \mathrm{~s} \\
2 & \mathrm{~h} \\
7 & \mathrm{~h} \\
1 & \mathrm{~d} \\
2 & \mathrm{~d} \\
3 & \mathrm{~d} \\
4 & \mathrm{~d} \\
5 & \mathrm{~d} \\
19 & \mathrm{~d} \\
47 & \mathrm{~d} \\
90 & \mathrm{~d}\end{array}$ \\
\hline
\end{tabular}

4.2.9 Measure $\mathrm{pH}$ of the leachate by pouring it directly into a $\mathrm{pH}$ measuring cup. Rinse the electrode with the sample in the cup and then replace it. Repeat this rinse two more times. Refill the cup and place a small stirring bar in the cup and record the $\mathrm{pH}$ (to the nearest 0.1 unit) when it has reached its maximum stable reading.

4.2.10 Rinse the syringe, syringe filter, and sample vials as described in section 3.6. Fill the vials with filtered leachate and label 


$$
\text { WHC-SD-W100-TC-001 REV. } 0
$$

the vial with traceable identification.

4.2.11 Submit samples for analysis and retain at least one sample as an archive.

\subsection{CALCULATIONS}

4.3.1 Surface Area $=2\left(\pi r^{2}\right)+2 \pi r h$

4.3.2 Volume $=\pi r^{2} h$

where: $r=$ radius of sample, $\mathrm{cm}$

$\mathrm{h}=$ height of sample, $\mathrm{cm}$

4.4 RECORDING OF DATA AND RESULTS

4.4.1 Record all data in a controlled laboratory notebook. Make entries so that analytical records for leachate analyses are traceable. 


\author{
WHC-SD-W100-TC-001 REV. 0 \\ $\mathrm{pH}$ of Solids by Electrometric Method
}

\title{
SCOPE
}

The $\mathrm{pH}$ of solids is measured by USEPA method 9045, Soil $\mathrm{pH}$. The solid sample is mixed with deionized water, and the $\mathrm{pH}$ of the slurry is then measured with a $\mathrm{pH}$ meter.

\section{APPLICATION}

This procedure will be used on cured cementitious products, and on unsolidified, surrogate waste to determine the corrosivity of the material.

\section{MATERIALS}

1. $\mathrm{pH}$ meter with means for temperature compensation.

2. Combination electrode.

3. $\quad 30-50 \mathrm{ml}$ plastic beaker

4. Squeeze bottle filled with deionized water

5. Secondary Standard Buffer saits: $\mathrm{pH}=4.00 ; \mathrm{pH}=7.00 ; \mathrm{pH}=10.00$

6. Magnetic stirrer

7. Teflon or glass coated stir bar

\section{PROCEDURE}

1. Assemble the $\mathrm{pH}$ electrode/pH metering system according to the manufacturer's operating manual.

2. Choose two buffers to for calibrating the pH system that will cover the expected $\mathrm{pH}$ range of the sample being measured, and are a minimum of three pH units apart (Alternatively, one can pre-mix the solid and water and place a drop of the liquid from the mixture onto litmus paper to determine the approximate $\mathrm{pH}$ of the solution/slurry.).

3. Calibrate the electrode for the two buffers chosen in step 2, following the $\mathrm{pH}$ probe/meter manufacturer's operating instructions. Repeat adjustments on successive portions of the two buffer solutions until readings are within $0.05 \mathrm{pH}$ units of the buffer value. Note the temperature of the buffer solution. Record the slope of the calibration.

3. Weigh out duplicate, 20.0 gram aliquots of solid into individual plastic beakers. Add 20.0 grams of deionized water to each and stir the suspensions for 30 minutes.

4. Allow the slurries to come to room temperature.

5. Adjust the electrode into its holder so that upon lowering into a sample, the electrode will be immersed just below the suspension. 
WHC-SD-W100-TC-001 REV. 0

6. Record the $\mathrm{pH}$ and temperature of the sample and its duplicate.

7. Rinse the $\mathrm{pH}$ probe and thermometer/thermocouple.

8. Repeat steps 3-7 for each sample. Perform calibration checks every 20 measurements or every hour. Recalibrate as necessary. 
WHC-SD-W100-TC-001 REV. 0

$\mathrm{pH}$ of liquids by Electrometric Method

\section{SCOPE}

The $\mathrm{pH}$ of 1 iquids is measured by USEPA method 9040 , $\mathrm{pH}$ Electrometric Measurement. The $\mathrm{pH}$ of an aqueous sample is measured with a $\mathrm{pH}$ meter ${ }^{6}$.

\section{APPLICATION}

This procedure will be used on aqueous solutions resulting from 90-day water leachates, and ANSI 16.1 Test leachates of cured cementitious specimens.

\section{MATERIALS}

1. $\mathrm{pH}$ meter with means for temperature compensation. A low sodium error electrode is suggested at $\mathrm{pH}$ levels $>10$.

2. Combination electrode.

3. $30-50 \mathrm{ml}$ plastic beaker

4. Squeeze bottle filled with deionized water.

5. Secondary Standard Buffer salts: $\mathrm{pH}=4.00 ; \mathrm{pH}=7.00 ; \mathrm{pH}=10.00$

6. Magnetic stirrer and glass stirring rod.

\section{PROCEDURE}

1. Assemble the $\mathrm{pH}$ electrode/pH metering system according to the manufacturer's operating manual.

2. Choose two buffers for calibrating the $\mathrm{pH}$ system that will cover the expected $\mathrm{pH}$ range of the sample being measured, and are a minimum of three pH units apart (Alternatively, one can pre-mix the solid and water and place a drop of the liquid from the mixture onto litmus paper to determine the approximate $\mathrm{pH}$ of the solution/slurry.).

3. Calibrate the electrode for the two buffers chosen in step 2, following the pH probe/meter manufacturer's operating instructions. Repeat adjustments on successive portions of the two buffer solutions until readings are within $0.05 \mathrm{pH}$ units of the buffer value. Record the slope of the calibration. Note the temperature of the buffer solution.

4. $\quad P l a c e$ about $30 \mathrm{ml}$ of the liquid sample into a clean plastic beaker, ensuring that the sensing portion of the electrode is immersed. Give adequate clearance for the stir bar to rotate.

5. Record the $\mathrm{pH}$ and temperature of the sample.

6. Rinse the $\mathrm{pH}$ probe and thermometer/thermocouple

7. Repeat steps 4-6 for each sample. Perform interim calibration checks every 20 measurements or every hour. Recalibrate as necessary. 
WHC-SD-W100-TC-001 REV. 0

THIS PAGE INTENTIONALLY LEFT BLANK 
WHC-SD-W100-TC-001 REV. 0

90-Day Water Iminersion

\section{SCOPE}

This method covers the water immersion procedure and apparatus used to test cementitous waste forms for evaluation of hydrological degradation. The immersion test covers conditions which simulate environmental elements to which waste forms may be subjected, either in shipping, storage or use.

\section{APPLICATION}

Solidified waste samples are submerged in deionized water for a period of 90 days, after which time they are removed from the water and examined for compressive strength. Wastes subject to this test must have cured for a minimum of 28 days, and must be removed from their curing molds.

\section{APPARATUS}

1. Deionized water

2. $50 \mathrm{~mm} \times 100 \mathrm{~mm}$ (diam $X$ height) cementitious waste specimen

3. $500 \mathrm{ml}$ glass jar with screw-cap lid.

4. Graduated cylinder, $250 \mathrm{ml}$

\section{PROCEDURE}

1. Label the $500 \mathrm{ml}$ (16 oz) glass jar for each specimen (re-use the outer jar that was used during the curing step). The label should show the sample identification and the date of immersion.

2. Remove the cement specimen from its plastic curing container and place it into the $500 \mathrm{ml}$ glass jar.

3. Measure 250 milliliters of water with a graduated cylinder and transfer the water to the glass jar.

4. Screw the lid onto the jar and seal around the lid with plastic tape.

5. Keep the specimen immersed for $90 \pm 2$ days, then remove the specimen from the jar, blot it dry with a paper towel. Immediately $(90 \pm 2$ days from beginning of leach) perform the compressive strength test on the specimen.

6. Measure the $\mathrm{pH}$ of the water leachate in the jar with a pH electrode. Record this value. 
WHC-SD-W100-TC-001 REV. 0

THIS PAGE INTENTIONALLY LEFT BLANK 


\author{
WHC-SD-W100-TC-001 REV. 0 \\ Toxicity Characteristic Leaching Procedure (TCLP)
}

\title{
1.0 SCOPE AND APPLICATION
}

1.1 The TCLP ${ }^{7}$ is designed to determine the mobility of inorganic analytes present in solid wastes as defined in section(s) 7.1.1 through 7.1 .4 of USEPA SW-846 Method 1311, TOXICITY CHARACTERISTIC LEACHING PROCEDURE. The waste sample will be mixed with cement, cured, crushed and analyzed for TCLP metals.

1.2 If a total analysis of the waste demonstrates that individual analytes are not present in the waste, or that they are present but at such low concentrations that the appropriate regulatory levels could not possibly be exceeded, the TCLP need not be run.

\subsection{SUMMARY OF METHOD}

2.1 For wastes containing greater than or equal to $0.5 \%$ solids, the liquid, if any, is separated from the solid phase and stored for later analysis; the particle size of the solid phase is reduced, if necessary. The solid phase is extracted with an amount of extraction fluid equal to 20 times the weight of the solid phase. The extraction fluid employed is a function of the alkalinity of the solid phase of the waste. A special extractor vessel is used when testing for volatile analytes (see Table 1 for a list of volatile compounds). Following extraction, the liquid extract is separated from the solid phase by filtration through a 0.6 to $0.8 \mu \mathrm{m}$ glass fiber filter.

\subsection{APPARATUS AND MATERIALS}

3.1 Agitation apparatus: The agitation apparatus must be capable of rotating the extraction vessel in an end-over-end fashion at $30 \pm 2 \mathrm{rpm}$.

3.2 Teflon Bottle - with sufficient capacity to hold the sample and the extraction fluid, designed to fit the agitation apparatus. Headspace is allowed in this vessel.

3.3. Filter Holder - capable of supporting a $47 \mathrm{~mm} \mathrm{glass}$ fiber filter. Must have a minimum internal volume of $300 \mathrm{~mL}$ and able to withstand the pressure needed to accomplish separation $345-483 \mathrm{kPa}(\sim 50-70$ psi).

3.4 Filters - Borosilicate glass fiber, no binder, effective pore size of 0.6 to $0.8 \mu \mathrm{m}$. Filters shall be acid-washed prior to use by rinsing with $1 \mathrm{~N}$ nitric acid followed by three consecutive rinses with deionized distilled water (a minimum of $1 \mathrm{~L}$ per rinse is 
recommended).

$3.5 \mathrm{pH}$ Meter - accurate to \pm 0.05 units at $25^{\circ} \mathrm{C}$.

3.6 Laboratory Balance - accurate to within \pm 0.01 grams. A11 weight measurements are to be within \pm 0.1 grams

3.7 Beaker or Erlenmeyer flask, glass, $500 \mathrm{~mL}$.

3.8 Watchglass, appropriate diameter to cover beaker or Erlenmeyer flask.

3.9 Magnetic stirrer.

\subsection{REAGENTS}

4.1 ACS Reagent grade chemicals shall be used in all tests. Uniess otherwise indicated.

4.2 Deionized Reagent Water, $\geq 17$ Mohm-cm.

4.3 Hydrochloric acid (1N), $\mathrm{HCl}$, made from ACS reagent-grade.

4.4 Nitric acid (IN), $\mathrm{HNO}_{3}$, made from ACS reagent grade.

4.5 Sodium hydroxide (1N), $\mathrm{NaOH}$, made from ACS reagent grade.

4.6 Glacial acetic acid, $\mathrm{CH}_{3} \mathrm{CH}_{2} \mathrm{OOH}$, ACS reagent grade.

4.7 Extraction fluid \# 1: Add $5.7 \mathrm{~mL}$ glacial $\mathrm{CH}_{3} \mathrm{CH}_{2} \mathrm{OOH}$ to $500 \mathrm{~mL}$ of reagent water, add $64.3 \mathrm{~mL}$ of $\mathrm{IN} \mathrm{NaOH}$, and dilute to a volume of 1 liter. When correctly prepared, the $\mathrm{pH}$ of this fluid will be $4.93 \pm 0.05$.

4.8 Extraction fluid \#2: Dilute $5.7 \mathrm{~mL}$ glacial $\mathrm{CH}_{3} \mathrm{CH}_{2} \mathrm{OOH}$ with reagent water to a volume of 1 liter. When correctly prepared, the $\mathrm{pH}$ of this fluid will be $2.88 \pm 0.05$.

\subsection{SAMPLE COLLECTION, AND HANDLING}

TCLP extracts should be prepared for analysis and analyzed as soon as possible following extraction. Extracts or portions of extracts for metallic analyte determinations must be acidified with nitric acid to a $\mathrm{pH}<2$, unless precipitation occurs (see Section 7.2.14 of Reference 7 if precipitation occurs). Extracts should be preserved for other analytes according to the guidance given in the individual analysis methods. See Section 7.0 (QA requirements) for acceptable sample and extract holding times. 
WHC-SD-W100-TC-001 REV. 0

\subsection{PROCEDURE}

6.1 Perform preliminary TCLP evaluations on a minimum 100 gram aliquot of waste. This aliquot may not actually undergo TCLP extraction. These preliminary evaluations include:

(1) Determination of whether the solid portion of the waste requires particle size reduction (Section 7.1.3 of Ref. 7).

Particle size reduction is required if the sample does not have a surface area per gram of material equal to or greater than $3.1 \mathrm{~cm}^{2}$, or is greater than $1 \mathrm{~cm}$ in its narrowest dimension (i.e., is not capable of passing through a $9.5 \mathrm{~mm}$ ( 0.375 inch) standard sieve). If the surface area is smaller or the particle size larger than described above, prepare the solid portion of the waste for extraction by crushing or cutting the waste to a surface area or particle size as described above.

Sieving of the cementitious samples is not normally required. Actual measurement of surface area is not recommended. If sieving is necessary, a stainless steel sieve should be used to avoid contamination of the sample.

(2) Determination of which of the two extraction fluids are to be used for the nonvolatile TCLP extraction of the waste Determination of appropriate extraction fluid:

1. Weigh out $5.0 \mathrm{~g}$ of the solid phase of the size-reduced $(<1 \mathrm{~mm}$ dia) sample and transfer it to a $500 \mathrm{~mL}$ beaker or Erlenmeyer flask.

2. Add $96.5 \mathrm{~mL}$ of reagent water to the beaker, cover with a watchglass, and stir vigorously for 5 minutes using a magnetic stirrer. Measure and record the $\mathrm{pH}$. If the $\mathrm{pH}$ is $<5.0$, use extraction fluid \#1.

3. If the $\mathrm{pH}$ from Step 2 above is $>5.0$, add $3.5 \mathrm{~mL} 1 \mathrm{~N}$ $\mathrm{HCl}$, slurry briefly, cover with a watchglass, heat to $50^{\circ} \mathrm{C}$, and hold at $50^{\circ} \mathrm{C}$ for 10 minutes.

4. Let the solution cool to room temperature and record the $\mathrm{pH}$. If the $\mathrm{pH}$ is $<5.0$, use extraction fluid \#1. If the $\mathrm{pH}$ is $>5.0$, use extraction fluid $\# 2$.

\subsection{Hour Extraction}

6.2.1 Prepare 120 grams of the waste for extraction by crushing or 


$$
\text { WHC-SD-W100-TC-001 REV. } 0
$$

cutting the waste to a surface area or particie size as described in Section 7.1(1).

\subsubsection{Transfer $100.0 \mathrm{~g}$ of the solid material into an extractor} bottle.

6.2.3 Determine the amount of extraction fluid to add to the extractor vessel as follows:

Weight of extraction fluid $=20 \times$ Weight of waste

6.2.4 Slowly add the appropriate extraction fluid to the extractor vessel, replace the cap and use Teflon ${ }^{\circledR}$ tape to ensure a tight seal.

6.2.5 Secure in rotary agitation device, and rotate at $30 \pm 2 \mathrm{rpm}$ for $18 \pm 2$ hours at $22 \pm 3^{\circ} \mathrm{C}$.

6.2.6 If necessary relieve pressure buildup in the extraction bottle after a periods of 15,30 , and 60 minutes. Vent into a hood.

6.3 Filtration Following $18 \mathrm{hr}$. Extraction.

6.3.1 Assemble the filter holder and filter following the manufacturer's directions. Secure the filter onto the support screen.

6.3.2 Gradually apply vacuum or gentle pressure of 7-69 $\mathrm{kPa}$ (1-10 psi) until air moves through the filter. Separate the material into its liquid and solid phases. If necessary, slowly increase in $69 \mathrm{kPa}$ increments at approximately 2 minute intervals to a maximum of $345 \mathrm{kPa}$. The glass fiber filter may be changed, if necessary, to facilitate filtration.

\subsection{Extract Preparation Following Extract Filtration}

6.4.1 The $\mathrm{pH}$ of the extract is measured and recorded using a $\mathrm{pH}$ meter.

6.4.2 Aliquot $100 \mathrm{ml}$ of the extract into a $150 \mathrm{ml}$ beaker and add $100 \mu \mathrm{L}$ of TCLP Matrix Spike Solution to the appropriate samples (see Section 8.2 of Ref. 7). Stir for 5 min. 
6.4.3 Acidify the extract ${ }^{1}$ (metal analysis preservation only) to a $\mathrm{pH}<2$ using $0.1 \mathrm{~N}$ nitric acid.

6.4.4 Aliquot $100 \mathrm{ml}$ of the preserved extract into clean ICHEM ${ }^{\odot}$ bottles, and ship to the appropriate laboratory for Acid Digestion, followed by TCLP metals analyses by ICP/AA or ICPMS.

\subsection{QUALITY CONTROL}

7.1 Prepare one acetic acid blank (using the same extraction fluid as used for the samples) for every 20 extractions (or less) that have been conducted in an extraction vessel.

7.2 Samples must undergo TCLP extraction within the following time periods:

Table 3. TCLP Sample Maximum Holding Times (days)

\begin{tabular}{||l|l|l|l|}
\hline & $\begin{array}{l}\text { From: Field Collection } \\
\text { TO: TCLP Extraction }\end{array}$ & $\begin{array}{l}\text { From: TCLP Extraction } \\
\text { TO: Analysis }\end{array}$ & Total Elapsed Time \\
\hline $\begin{array}{l}\text { ICP } \\
\text { (Ag, Ba, Cd, Cr, Pb) }\end{array}$ & 180 & 180 & 360 \\
\hline$A A(A s, S e)$ & 180 & 180 & 360 \\
\hline$A A(H g)$ & 28 & 28 & 56 \\
\hline
\end{tabular}

If sample holding times are exceeded, the values obtained will be considered minimal concentrations. Exceeding the holding time is not acceptable in establishing that a waste does not exceed the regulatory level. Exceeding the holding time will not invalidate characterization if the waste exceeds the regulatory level.

1 If precipitation is observed upon addition of nitric acid to a small a) iquot of the extract, then the remaining portion of the extract for metals analyses shall not be acidified and the extract shall be analyzed as soon as possible. 
WHC-SD-W100-TC-001 REV. 0

THIS PAGE INTENTIONALLY LEFT BLANK 


\section{WHC-SD-W100-TC-001 REV. 0 \\ References}

1. WHC-SD-W100-TP-011, CEL Working Procedures for WRAP 2A Formulation Development Tests, 1994, WHC, Richland, WA.

2. WHC-SD-W100-AP-002, Rev. $0 ; 183-H$ Basin Sludge Treatabilty Testing Program Plan. September 1994.

3. Time Setting of Concrete Mixtures by Penetration Resistance, American Society for Testing and Materials (ASTM), Method C-403-70, 1979.

4. Standard Test Method for Compressive Strength of Cylindrical Concrete Specimens), C 39-86, 1986 Annual Book of ASTM Standards.

5. American Nuclear Society (ANS), 1986. Measurement of the Leachability of Solidified Low-Level Radioactive Wastes by a Short-Term Test Procedure: ANSI/ANS-16.1, American Nuclear Society, Champaign, Illinois.

6. United States Environmental Protection Agency, Test Methods for Evaluating Solid Waste, SW-846 Method 9040, Rev. 0, Sept. 1986.

7. United States Environmental Protection Agency, Test Methods for Evaluating Solid Waste. Physical/Chemical Methods, SW-846, Method 1311, Rev 0, 1990. 